Open Access

International Journal of Agricultural and Applied Sciences, June 2020, 1(1): 22-26

https://www.agetds.com/ijaas

ISSN: 2582-8053

https://doi.org/10.52804/ijaas2020.115

Research Article

\title{
Effect of weed control on weeds, grain yield and its components of maize (Zea mays $\mathbf{L}$ )
}

\author{
Ola Zakaria El-Badry and El-Sayed Gheith* \\ Agronomy Department, Faculty of Agriculture, Cairo University, Egypt \\ *Corresponding author e-mail: gheith2010@yahoo.com
}

(Received: 30/04/2020; Revised: 20/05/2020; Accepted: 29/05/2020)

\begin{abstract}
The present study entitled "effect of weed control on weeds, grain yield and its components of maize (Zea mays L.) cv. Single cross-10 was carried out at the Agricultural and Experiments Research Station at Giza, Faculty of Agriculture, Cairo University, Egypt. The experiment was conducted in the summer 2017 and was repeated in 2018 on the same piece of land to conform previous findings. The experiment design was Randomized Complete Block design (RCBD) having three replications. Six treatments include atrazine $(1.0 \mathrm{~kg} / \mathrm{ha})$, glyphosate $(0.8 \mathrm{~kg} / \mathrm{ha})$. atrazine + glyphosate, one hand hoeing after three weeks, hand hoeing twice after three and five weeks from sowing and weedy chick as control were used. Results indicated that glyphosate was found superior to atrazine for all studied characters. Moreover, lower weed dry matter accumulation and higher weed control \% as well as higher values of ear characters ( ear length, ear diameter, grain weight/ear and shilling \%) and grain yield per unit area were recorded in tank mix application of atrazine + glyphosate followed by hand hoeing twice.
\end{abstract}

Keywords: Maize, yield, yield components and weed control.

\section{INTRODUCTION}

Maize (Zea mays L.) occupies the key place in the cropping system of Egypt for it is a short duration crop and provides a more economic return to the farmers. It is the third most important staple food crop both in terms of area and production after wheat and rice in Egypt. The total area under cultivation of maize in Egypt is about 1.03 million hectares which is about $25.2 \%$ of the total cultivated agricultural land, which the average yield is 8.3 t/ha (FAOSTAT, 2016). Therefore, increasing maize production is an important goal to reduce the gap between production and consumption through expanding the maize cultivated area and increasing productivity per unit area. Consequently, increasing maize production under Egyptian conditions is major concern of agronomists. Despite average yield of maize is very low. The reassures for low yield are many, but one of the most serious and less noticeable, is the competition of weeds. Weeds have such significant effects on crop yield because they interfere with normal growth of crop, through competition for nutrients, moisture, space, sunlight, carbon dioxide and water. Weeds also serve as host for various pests and deceases that produce chemical substances that can be allergens or toxins to crop plant. There are also indication that weeds limit the choice of crop rotation sequences and culture practices (Patel et al., 2013). Moreover, weeds constituent one of the major economic important problem for maize growers, because they can reduce yield up 80\% (Konnan and Chinnagounder, 2013), 20 $100 \%$ (Madhaevi et al., 2014), 83\% (Ehsas et al., 2016), 18 -855 ( Jagadish et al., (2016) and 335 ( Kakade et al., 2016). The mechanical method of weed control is however the most commonly used method, very laborious, time consuming and very expensive, especially in the hot. Many previous researchers found that the maximum and minimum weed density and dry weight of all major weed species were recorded in hand hoeing treatments (Ahmed and Susheela, 2103; Kumar et al., 2013; Deshmukh et al., 2014; Samanth et al., 2015; Swetha et al, 2016 and Kumar,2017). On the other hand, chemical control method is quick, more effect, time and labor saving method than others. Herbicides controlled $65-90 \%$ of weed flora and gave $100-105 \%$ more maize yield than weedy cheek (Nadeem et al., 2005). Consequently, the present study aimed to investigate the effect of weed control on weeds, grain yield and its components of maize (Zea mays L.)..

\section{MATERIALS AND METHODS}

The present study entitled "effect of weed control on weeds, grain yield and its components of maize (Zea mays L.) cv. Single cross-10 was carried out at the 
Agricultural and Experiments Research Station at Giza, Faculty of Agriculture, Cairo University, Egypt. The experiment was conducted in the summer season 2017 and was repeated in 2018 on the same piece of land to conform previous findings. The experiment design was Randomized Complete Block design (RCBD) having three replications. The net plot area was $10.5 \mathrm{~m}^{2}$ (5 ridges, $3 \mathrm{~m}$ long and $70 \mathrm{~cm}$ apart). The soil type was clay loam in texture having 1.7 organic matter, $48.2 \mathrm{ppm}$ available $\mathrm{N}, 14.5 \mathrm{ppm}$ available $\mathrm{P}, 367.5 \mathrm{ppm}$ available $\mathrm{K}, 7.7 \mathrm{pH}$ and $2.4 \mathrm{mmohs} / \mathrm{cm} 25 \mathrm{c}^{0} \mathrm{Ec}$ (average of both seasons). Six treatments include atrazine alone (1.5 $\mathrm{kg} / \mathrm{ha})$, glyphosate alone $(0.8 \mathrm{~kg} / \mathrm{ha})$. atrazine + glyphosate, one hand hoeing after three weeks, hand hoeing twice after three and five weeks from sowing and weedy chick as control were used (Table 1).

Table 1: List of weed control treatments used in both season.

\begin{tabular}{|l|l|l|}
\hline $\begin{array}{l}\text { Trade } \\
\text { name }\end{array}$ & Common name & Dose/ha \\
\hline Atrazine & Basta & $1.5 \mathrm{~kg}$ \\
\hline Glphosate & $\begin{array}{l}\text { Touchdown } \\
\text { (roundup) }\end{array}$ & $0.8 \mathrm{~kg}$ \\
\hline $\begin{array}{l}\text { Atrazine + } \\
\text { glphosate }\end{array}$ & $\begin{array}{l}\text { Basta + } \\
\text { Touchdown } \\
\text { (roundup) }\end{array}$ & $\begin{array}{l}1.5 \mathrm{~kg}+ \\
0.8 \mathrm{~kg}\end{array}$ \\
\hline $\begin{array}{l}\text { One hand } \\
\text { hoeing }\end{array}$ & - & - \\
\hline $\begin{array}{l}\text { Two hand } \\
\text { hoeing }\end{array}$ & - & - \\
\hline $\begin{array}{l}\text { Unweeded } \\
\text { (control) }\end{array}$ & - & - \\
\hline
\end{tabular}

Two grains of Maize (cv. Single cross 10)) were sown manually in each hill at $25 \mathrm{~cm}$ spacing and irrigation was followed. Date of sowing was in the fourth week of May in both seasons. Thinning to one plant/hill was done before the first irrigation (3 weeks after sowing). The recommended amount of nitrogen (urea $46.5 \%$ ) and phosphorus (DAP) were applied. Half of nitrogen and the whole of phosphorus were drilled in ridges at the time of sowing and the reaming half of nitrogen was applied before the first irrigation. All other agronomic practices followed uniformly for all treatments through the growing seasons. Herbicides at the recommended doses were applied in the plots at $4^{\text {th }}$ week after sowing of maize followed by irrigation. The herbicides were applied by a knapsack-sprayer using $700 \mathrm{~L}$ water/ha. The data on weed biomass was collected at 90 days after sowing from $1 \mathrm{~m}^{2}$ in each plot. The collected weeds were dried in the sun and then in a electrical oven for 48 hours maintain a constant temperature of $75 \mathrm{c}^{0}$. After drying, weight of dry weeds $\left(\mathrm{g} / \mathrm{m}^{2}\right)$ was measured. At harvest, plant height, grain weight/ear, 100 -grain weight and grain yield per unit area were estimated. The recorded data were analyzed by using statistical software package MSTAT-C (Michigan State University, 1990). Least significant differences (L.S.D.) at $0.05 \%$ probability was employed to test the significant differences among mean value of each treatment (Steel and Torrie, 1997).

\section{RESULTUS AND DISCUTION}

\section{Effect on weeds}

The results presented in Table (2) indicated that the experiments were infested with several broad leaf and grasses weeds.. The family Compositae included Xnthum pongens, while Ceperaceae included Cyperus rotundus and Euphorbiaceae included Euphorbia geniculala. The family Poaceace predominated the other families having three species viz. Brachiaria eruciformis, Echinochloa colonum, , Cynodon dactyilon. Moreover, Portulaceae and Tiliaceae included Portulacae oleracea and Corchorus olitorius, respectively (Table 2 ).

Table 2: Prevailed weeds in the experimental area in both season.

\begin{tabular}{|l|l|l|}
\hline Botanical name & Family & $\begin{array}{l}\text { English } \\
\text { name }\end{array}$ \\
\hline $\begin{array}{l}\text { Amaranthus } \\
\text { oleraceea } \text { L. }\end{array}$ & Amaranthaceae & Pigweed \\
\hline $\begin{array}{l}\text { Xnthum pongens } \\
\text { L. }\end{array}$ & Compositae & Cocklebur \\
\hline $\begin{array}{l}\text { Cyperus rotundus } \\
\text { L. }\end{array}$ & Cyperaceae & $\begin{array}{l}\text { Purble } \\
\text { Nutsedge }\end{array}$ \\
\hline $\begin{array}{l}\text { Euphorbia } \\
\text { geniculala } \text { L. }\end{array}$ & Euphorbiaceae & Spurge \\
\hline $\begin{array}{l}\text { Echinochloa } \\
\text { colonum } \text { L. }\end{array}$ & Poaceae & Grass Jungle \\
\hline $\begin{array}{l}\text { Prachiaria } \\
\text { eruciformis } \text { L. }\end{array}$ & Poaceae & Broadleaf \\
\hline $\begin{array}{l}\text { Cymodon } \\
\text { dactylon L. }\end{array}$ & Poaceae & $\begin{array}{l}\text { Eermoda } \\
\text { grass }\end{array}$ \\
\hline $\begin{array}{l}\text { Portulacae } \\
\text { oleracea L. }\end{array}$ & Portulaceae & Pursian \\
\hline $\begin{array}{l}\text { Corchorus } \\
\text { olitorius } \text { L. }\end{array}$ & Tiliaceae & Nalta Jute \\
\hline
\end{tabular}

Concerning dry weight of weeds $/ \mathrm{m}^{2}$, results in Table (3) showed that atrazine plus ghlphosate followed by hand hoeing twice reduced dry weight of weed $/ \mathrm{m}^{2}$ compared with other treatments. On the other hand, either atrazine alone or ghlyphosate alone and one hand hoeing were moderate in controlling grassy weeds compared to unwedded (control) in both seasons. Moreover, atrazine + glyphosate, hand hoeing twice, atrazine alone, glyphosate alone and one hand hoeing reduced the dry weight of total weeds by ( 84.1 and $114.7 \mathrm{gm}),(69.7$ and $78.5 \mathrm{gm}),(34.5$ and $35.1 \mathrm{gm})$, (24.6 and $25.1 \mathrm{gm})$ and (14.5 and $19.8 \mathrm{gm}$ ) than those that in control (112.6 and $135.3 \mathrm{gm}$ ) in both season, 
respectively. Therefore, weed control (\%) over the untreated control were (74.7 and 84.6\%),(61.9 and $58.0 \%$ ). (30.7 and 25.9\%), 21.8 and 18.6\%) and (12.9 and $14.6 \%$ ) in both seasons, respectively. Generally, atrazine + glyphosate was the best in controlling weeds in maize followed by hand hoeing twice. On the other hand, ghlphosate alone followed by one hand hoeing was the poorest in decreasing dry weight of total weeds in both seasons. The reduction in dry weight of weeds may be due to the phototoxic effect of herbicides on weeds. This findings are in harmony with the previous work of Madhavi et al. (2014), Samanth et al. (2015),
Stanzen et al. (2016), Kumar et al. (2017) and Suhoo et al. (2017) who reported that the minimum dry weight of all major weed species and the maximum grain yield of maize were recorded in two hand hoeing and application of different herbicides. Moreover, Tahir (2007) indicated that the lower weed dry weight due to herbicide and manual hoeing application over weedy check might have been due to the mortality of weeds in these treatments while, the maximum weed dry weight was found in weedy check due to unchecked weed growth as no weed control practices were applied.

Table 3: Effect of weed control treatments on dry weight of total weeds $\left(\mathrm{gm} / \mathrm{m}^{2}\right)$ and weed control (\%) in both seasons.

\begin{tabular}{|l|c|c|c|c|}
\hline \multicolumn{1}{|c|}{ Treatments } & $\begin{array}{c}\text { Dry weight of } \\
\text { total weeds }\end{array}$ & $\begin{array}{c}\text { Weed control } \\
(\%)\end{array}$ & $\begin{array}{c}\text { Dry weight of } \\
\text { total weeds }\end{array}$ & $\begin{array}{c}\text { Weed } \\
\text { control }(\%)\end{array}$ \\
\hline & \multicolumn{2}{|c|}{ First season (2017) } & \multicolumn{2}{c|}{ Second season (2018) } \\
\hline Atrazine & 78.1 & 30.6 & 100.2 & 25.9 \\
\hline Glyphosate & 88.0 & 21.8 & 110.2 & 18.6 \\
\hline Atrazine + ghlyphosate & 28.5 & 74.9 & 20.6 & 84.8 \\
\hline One hand hoeing & 98.1 & 12.9 & 115.5 & 14.6 \\
\hline Two hand hoeing & 42.9 & 61.9 & 56.8 & 58.0 \\
\hline Nunweeded (control) & 112.6 & 00.0 & 135.3 & 00.0 \\
\hline L.S.D. & 8.3 & & 6.8 & \\
\hline
\end{tabular}

Table 4: Effect of weed control treatments on plant height, ear length, grain weight/ear, 100-grain weight and grain yield in the first season.

\begin{tabular}{|l|c|c|c|c|c|c|}
\hline \multicolumn{1}{|c|}{ Treatments } & $\begin{array}{c}\text { Plant } \\
\text { height } \\
(\mathrm{cm})\end{array}$ & $\begin{array}{c}\text { Ear length } \\
(\mathrm{cm})\end{array}$ & $\begin{array}{c}\text { Grain } \\
\text { Weight } \\
\text { /ear }(\mathrm{g})\end{array}$ & $\begin{array}{c}\text { 100-grain } \\
\text { Weight }(\mathrm{g})\end{array}$ & $\begin{array}{l}\text { Grain } \\
\text { Yield (t/ha) }\end{array}$ & $\begin{array}{c}\text { Relative increase } \\
(\%) \\
\text { increase }\end{array}$ \\
\hline Atrazine & 269.1 & 21.4 & 224.1 & 39.1 & 3.7 & 48.0 \\
\hline Glyphosate & 267.2 & 21.2 & 215.5 & 36.9 & 3.3 & 32.0 \\
\hline Atrazine + Glyphosate & 273.3 & 23.9 & 230.2 & 43.1 & 4.6 & 84.0 \\
\hline One hand hoeing & 265.1 & 21.0 & 210.3 & 37.5 & 3.9 & 56.0 \\
\hline Two hand hoeing & 271.2 & 22.9 & 227.2 & 41.3 & 4.2 & 68.0 \\
\hline Nunweeded (control) & 260.0 & 20.8 & 160.5 & 33.2 & 2.5 & 00.0 \\
\hline L.S.D. & 2.1 & 1.0 & 3.0 & 2.2 & 0.4 & \\
\hline
\end{tabular}

Table 5: Effect of weed control treatments on plant height, ear length, grain weight/ear, 100-grain weight and grain yield in the second season.

\begin{tabular}{|l|c|c|c|c|c|c|}
\hline \multicolumn{1}{|c|}{ Treatments } & $\begin{array}{c}\text { Plant } \\
\text { height } \\
(\mathrm{cm})\end{array}$ & $\begin{array}{c}\text { Ear length } \\
(\mathrm{cm})\end{array}$ & $\begin{array}{c}\text { Grain } \\
\text { weight } \\
\text { /ear }(\mathrm{g})\end{array}$ & $\begin{array}{c}\text { 100-grain } \\
\text { Weight }(\mathrm{g})\end{array}$ & $\begin{array}{c}\text { Grain } \\
\text { Yield (t/ha) }\end{array}$ & $\begin{array}{c}\text { Relative increase } \\
(\%) \text { increase }\end{array}$ \\
\hline Atrazine & 270.1 & 20.2 & 210.1 & 40.3 & 3.8 & 65.2 \\
\hline Glyphosate & 268.6 & 20.1 & 205.3 & 38.7 & 3.5 & 52.2 \\
\hline Atrazine + Glyphosate & 276.2 & 23.3 & 225.3 & 44.1 & 4.4 & 91.3 \\
\hline One hand hoeing & 266.8 & 20.3 & 200.1 & 35.8 & 3.1 & 34.8 \\
\hline Two hand hoeing & 272.5 & 22.7 & 220.2 & 42.5 & 4.1 & 78.3 \\
\hline Nunweeded (control) & 262.1 & 20.2 & 165.3 & 34.2 & 2.3 & 00.0 \\
\hline L.S.D. & 3.8 & 2.3 & 4.3 & 1.6 & 0.3 & \\
\hline
\end{tabular}

\section{Effect on grain yield and its related traits}

The final grain yield of maize crop is a function of combined effect of ear characters and number of ears per unit area which were affected by the management practices. The results presented in Table (4 and 5) raveled that plant height, ear length, grain weight/ear, 100-grain weight and grain yield per unit area were significantly affected with all tested treatments in both seasons. The tallest plants $(273.3$ and $276.2 \mathrm{~cm})$, the highest ear length $(23.9$ and $23.3 \mathrm{~cm})$, the highest grain weight/ear (230.2 and $225.3 \mathrm{gm})$ the highest 100-grain weight (43.1 and 44.1) and the highest grain yield (4.6 and $4.4 \mathrm{t} / \mathrm{ha}$ ) were recorded with application of atrazine 
+ glyphosate in both seasons, respectively. On the other hand, the other evaluated treatments showed an intermediate effect. Moreover, weed infested plots gave the shortest plants ( 260.0 and $262.1 \mathrm{~cm}$ ), shortest ear length (20.8 and $20.2 \mathrm{~cm})$, lowest grain weight/ear (160.5 and $165.3 \mathrm{gm})$, lowest 100-grain weight ( 33.2 and $34.2 \mathrm{gm}$ ) and the lowest grain yield ( 2.5 and $2.3 \mathrm{t} / \mathrm{ha}$ ) in both season, respectively. It is quite clear from the demonstrated results that application of atrazine + ghlyphosate significantly increased grain yield by $84 \%$ in the first season and by $91 \%$ in the second one over the infested control. Such results may be due to the better control of weeds by mixture of the two tested herbicides which contribute to higher grain yield. The increment in grain yield was mainly because of more ear length, grain weight/ear and 100-grain weight over weedy check which recorded the lowest grain yield could be attributed to maximum weed density which suppressed the growth and development of maize plants by competing for moisture, light and nutrients (Tahir, 2009). These results are agreement with those obtained by many researchers (Stanzen et al., 2016; Kumar et al., 2017; and Sahoo et al., 2017)

who reported that either herbicides or hand hoeing significantly decreased weed population and competition over control and maximum grain yield was obtained.

\section{REFERENCES}

Ahmed. M.A.A. and Susheela, R. 2012. Weed management studies in Kharif maize. Research Notes, Journal Res. ANGARAU, 40(3);121-123.

Deshmukh, J. P.; P. v. Simgruo; M. S. Dandge; V. M. Bhale and Postawar, A. N. 2014. Integrated weed management in maize. Binnal Conference of Indian Society of Weed Science on " Emergence Challenges in weed management". Directorate of Weed Science Research, Jabalpur, Madhya, Pradesh, India, 81 pp 33.

Ehsas, J.; L. J. Desai; N. B. Ahir and Jashi. J. R. 2016. Effect of integrated weed management on growth, yield and yield attributes and weed parameters on summer maize (Zea mays L.) under South Gujarat condition. International Journal of Science. Environment and Technology. 5(4):2050-2056.

FAOSTAT 2016. Population Data. Food an Agricultural Organization of United Nation, Roma. On line at http:llFaostat.fao. org/download /0/OA/E.

Jagadish, J. and Prashant, C. S. 2016. A review weed management on maize (Zea mays L.). Advances in Life Sciences, 5(9):3448-3455.
Kakade, S. U.; J. P. Deshmulkh; V. M. Bhale; M. S. Solankr and Shingrup, P. V. 2016. Efficiency of pre and post emergence herbicides in maize. Extend Summaries Vol. 1: $4^{\text {th }}$ International Agronomy Congress, Nov. 22-26, 2016, New Delhi, India, pp 442-443.

Konnan, S. and Chinnagounder, C. 2013. Effect of glyphosate on weed mangemrnt and grain yield in Kharif maize hybrids for higher productivity. Academic journals, 9(2);269-273.

Kumar, B.; R. Kumal; S. Kelyani and Hagua, M. 2013. Integrated weed management studies on weed flora and yield on Kharif maize. Trends in Biosciences, 6(2):161-164.

Kumar, B.; S. Prosad; D. Mandal and Kumar. R. 2017. Influence of integrated weed management practices on weed dynamics, productivity and nutrient uptake of Rabi maize (Zea mays L.). International Journal of Current Microbiology and Applied Science, 6(4):1431-1440.

Madhavi, M.; T. Ramprakash; A. Srinivas and yakadri, M. 2014. Topramezone (33.610. SC) + atrazine $(50 \%)$ tank mix efficiency on maize Brennial. Confference on "Emergence challenge in weed management" Organized by Indian Society of weed Science, 15-17 February, Michigan State University 1990. 4 Series Guide to MSTAT-C. Michigan.

Mukherjee, P.K.; P.M. Bhattacharya and Chowdhury, A.K. 2001. Weed control in wheat (Triticum aestivum $\mathrm{L}$.) under terai-agroecological region of West Bangl. J. Weed Res., 3(2):30-35.

Nadeem, M. A,; S, M. Awai; M. Ayube; M. Tahir and Maqpool. O. M. 2010. Integrated weed management studies for autumn planted maize. Pakistan Journal of Life Science Society, 8(2):98-101.

Patel, R. H. et al. 2013. Weed dynamics as influenced by soil solarization-A review. Agric. Rev., 26: 292-300.

Sahoo, T. R.; U. K. Paikaray; U. Mohapatra and Sethi, D. 2017. Saflufenacil: A new group of chemical herbicide for effective weed management in maize. International Journal of Chemical Studies, 5(1):339-342.

Samanth, T. K.; B. C. Dhir and Mohanty, B. 2015.Weed growth, yield components, productivity, economics and nutrient uptake of maize (Zea mays L.) as affected by various herbicides application under rainfed condition. Indian Journal of Weed Science, 2(1): 79-83. 
Stanzen, L.; A. Kumar; B. C. Sharma; R. Pumiya and Sharma, A. 2016. Weed dynamics and productivity under different tillage and weedmangement practices in maize (Zea mays)wheat (Triticum aestivum) cropping sequence. Indian Journal of Agronomy, 61(44):449-454.

Steel, R.C. and Torrie, J.H. 1997. In Principles and Procedures of Statistics. A biometrical Approach. $2^{\text {nd }}$ ed., McGraw-Hill Book Co., Inc. New York, USA, 633P.
Tahir, M.; Rashad Javed; Asif Tanweer; M. Ather Nadeem; Altah Nadeem; Altah Wasaya; S. A. H. Bukari and Jamil-Ur-Rehman (2009). Effect of different herbicides on weeds, growth and yield of spring planted maize ( Zea mays L.). Pakistan Journal of Life Society Science, 7(2):168-174

Swetha, K. 2015. Weed management with new generation herbicides in Kharif maize (Zea mays L.). (M. S. (Ag) Thesis). Professor Jayashankar Telangana State Agricultural University, Hyderabad, India. 